\title{
Effect of Smoking For Teens Against Behavior and Social Interaction
}

\author{
Muhammad Ali Sodik, Aprina Titin Setyani \\ STIKes Surya Mitra Husada \\ Alisodik2012@gmail.com Aprinatitin22@gmail.com
}

\begin{abstract}
Adolescence is a period where an individual experiencing a transition from one stage to the next and either change the emotions, body, mint pattern of behavior, and also full-masalahRemaja problems tend to have a curiosity for the big smoke. Smoking habits for teenagers started because of lack of information and misunderstanding of information, advertising or seduced seduction inedible friend. Many people believe that smoking can relieve stress. However it is very justified. It is only the effect of nicotine that nature provides a sense of calm for a moment. If you already smoke laungkan time to stop as soon as possible of the bad habits. Ranging from healthy living and regularly keeping in dangers of smoking to health was terrible.
\end{abstract}

Keywords: smoking, teen, nicotine.

\section{Background}

Adolescence is a period where an individual experiencing a transition from one stage to the next and either change the emotions, body, mint pattern of behavior, and also filled with problems. Therefore, adolescents are highly vulnerable to experiencing psychosocial, ie psychological or psychiatric problems that arise as a result of social change.

Actually, a student is not allowed to smoke in the school, the community or the other. Because this can be bad for health. Usually this is done by teenagers because of their emotional state is not stable to make them do things. It is in sebababkan lack of education about smoking among sekolahatau bahay society.

Smoking is one of the problems that are difficult to solve. Moreover, already a national problem, and even internationally. It ininmenjadi difficult, because it is associated with many mutual facto trigger, so it seems has become a vicious circle. In the review in terms of health, smoking should be stopped because it causes cancer in blockage of blood vessels resulting in kematia, therefore smoking should be stopped as early as possible prevention efforts. Moreover, note that most are teenagers so perluadanya early prevention which starts from the school and parents. 
Smokers feel the pleasure of smoking is so obvious, until perceived provide pleasant and refreshing taste that every day should be set aside money for smoking. Other groups, especially young men, they think smoking is a hallmark of masculinity that boast, so that those who do not smoke even just ridiculed. Though they are aware that smoking can harm health and even lead to many serious diseases. Many of the contents are harmful in cigarettes that cause adverse effects on health.

\section{Problem}

Photo Jakarta- two vocational students who were smoking when pursuing a classroom teacher became viral on social media. Teachers in these classes do not know of students who smoke during hours pelajaranya. Here's the chronology of events as stated by the Head of SMK PGRI 38 Sedya Basuki told reporters on Thursday (07/27/2017) in a written statement.

On Wednesday, July 26, 2017, around 12.30, we (Principal SMK PGRI 38) was told by one of the teachers there are postings SMA PGRI students who were smoking in the classroom. The student smoking in the classroom and the teachers who are teaching.

\section{Literature review}

Understanding cigarette according to PP 81/1999 Article 1, paragraph 1 is processed wrapped tobacco including cigars or other forms resulting from the plant Nicotiana tabacum, Nicotiana rustica and other species or synthetic containing nicotine and tare with or without additives.

According to Ogawa (in Triyanti 2006) formerly called the smoking behavior as a habit or addiction, but this adult smoking in tobaco dependencyd call itself can be defined as the use of tobacco sedentary behavior, usually more than half a pack per day.

1. Factors that influence smoking behavior

According Juniarti (1991) in Mu'tadin (2002) in the Department of Health Polytechnic Jakarta 1 (2012), factors that influence smoking habits are as follows:

a. Influence of Parents

One of the findings of adolescent smokers is that young people who come from homes that are not happy, where parents paid little attention to their children and provide harsh penalties.

b. The influence of friends More and more teenagers who smoke, the more likely her friends are smokers and 
demekian vice versa. From these facts there are two possibilities occur. First, a teenager was influenced by his friends, or even my friends teenagers are influenced by the youth.

c. factors kepribaian

People try to smoke for some reason want to know tau want to escape from physical or mental pain and rid themselves of boredom.

d. the influence of advertising Viewed in the media advertising and electronic mass arrives presents a picture that smokers are the symbol of virility or glamor. Make teenagers often triggered to mimic the behavior of such behavior is in the ad

2. Aspects of Smoking Aspects of smoking behavior by Arita (in Nasution, 2007), namely:

a. Smoke function in everyday life

The function of smoke indicated the feelings experienced by the smoker, like feeling positive or negative feelings.

b. intensity of smoking
Smet (1994) clarifies the smokers based on the number of cigarettes smoked, namely:

a. Heavy smokers who smoked more than 15 cigarettes a day

b. Moderate smokers who smoked 5-14 cigarettes preformance batag day

c. Light smokers who smoked 14 cigarettes a day.

c. Smoking area

Berdaarkan smokers mode where there are two (Mu'tadin 2002 in Jakarta I Poltekes MOH, 2012), namely:

a. Smoking in public places / public

b. Smoking in places that are personal

d. Smoking time

Smoking behavior is influenced by the circumstances that happened at that time, for example, is hanging with friends.

There are three indicators that usually appear on smokers:
a. physical activity
b. psychological activity
c. Smoking intensity is high enough.

\section{Discussion}
A. understanding cigarettes 
Smoking is a cylinder of paper between $70-120 \mathrm{~mm}$ in length with a diameter of $10 \mathrm{~mm}$ containing tobacco leaves that have been chopped. Cigarettes burn at one end and allowed to smolder so that the smoke inhaled through the mouth at the other end. The basic ingredients of cigarettes is tobacco. Tobacco is composed of various chemicals that can make people addicted, even though they do not want to try it again.

B. Impact of Smoking Behavior

\section{- For yourself}

1. Smoking more harm than good for the body.

2. Elicit suggestions to us, that if we do not smoke mouth uncomfortable and acids.

3. curiosity, passion for learning, and positive things that exist in us missing when we become a smoker.

- For others

1. When we were smoking, cigarette smoke we adapat disturbing others and also causes air pollution.

2. Causing a person close to us to be passive smokers.

3. If you throw cigarette butts carelessly without first turning off can cause a fire.

4. causing depletion of the ozone layer.
C. The factors that cause young people smoking

a.faktorsosial biggest factor of smoking is influenced by social or environmental factors, of which many a person's character is formed by the surrounding environment, whether family, neighbors, or friends pergaulannya.Bersosialisasi is the main way in children and adolescents to seek their identity mereka.Dengan see what other people do and sometimes try to imitate what the item to another person is a process that occurs in adolescents to seek their identity and learn to live bersosial.Namun very unfortunate, not only the good habits are imitated but bad habits, including smoking.

b. The need to suck and chew

Everyone has a need to suck and chew. This requirement existed since we were born, namely the need to drink milk, and gradually decrease and disappear, but in some people they last until adulthood. Some people use cigarettes or smoking devices and smoke as a means to meet these needs.

ResponmengulangotomatisWhen someone has done something many times and quite often, it will create a pattern of repetition of certain 
behaviors automatically. This is especially true if a particular action is done in an unpleasant situation, which gives the effect of making a person feel more secure in their daily lives and routines.

\section{d.FaktorGenetik}

Not everyone is highly dependent on nicotine. There are some people more easily addicted to nicotine than others, for reasons that are still hard to understand. And those reasons are believed diwariskandalamkodegenetik. e.KecanduanPadaSelSyaraf

Brain normally have substances that provide a calming effect and stimulating effect on nerve cells, where these substances work by attaching to receptors of nerve cells. And nicotine has the same effect as those substances on the nerve, when nicotine attaches to receptorsreseptordisel-selsaraf.

With the attachment of the nicotine receptors, the brain produces dopamine. Dopamine is what gives a soothing effect and stimulate other organs, which gives a nice effect of smoke ..

\section{Conclusion}

Almost all teenagers in Indonesia civilize smoking as usual activities while yangberdampak the dangers of smoking is bad for health or for others, the disease was not unusual to cause kematia. The urge to quit smoking for teens that is the intention of yourself and also encouragement from others. That can be done is to hold counseling about the dangers of smoking. If not stopped early on will berdmpak bad old days later.

\section{Reference}

1) Al Annas, S. N. N., Indasah, I., Yudhana, A., \& Sodik, M. A. (2018). Analysis of Using Basic Material and Process on Organoleptic Result of Tempe Chips in Ngantru Trenggalek. Indonesian Journal of Nutritional Epidemiology and Reproductive, 1(1), 46-55.

2) Sodik, M. A., \& Nahak, T. (2018). Incidence of Malaria, Prevention behavior and Nutritional Status: Analysis Of Factors That Cause Malaria Diseases In Umalor Village District Of West Malacca. Indonesian Journal of Nutritional Epidemiology and Reproductive, 1(1), 1120.

3) Azzard.2015.contoh makalah tentang pengaruh merokok bagi anak di bawah umut terhadap perilaku dan pergaulan sehari-hari. 
http://azarrd.blogspot.com/2015/02/conto

h-makalah-tentang-pengaruh-

merokok.html?m=1. 26 Mei 2018 (09:46)

4) Enha,D.2012. Coretan Sebuah Kisah. http://dedyenha.blogspot.co.id/2012/03/m akalah-perilaku-merokok-padaremaja.html?m=1.26 Mei 2018 (11.02)

5) Perdana,S. 8 kandungan dalam rokok an bahaya bagi tubuh. https://hellosehat.com/pusat-

kesehatan/berhenti-merokok/8-

kandungan-berbahaya-dalam-rokok-danpengaruhnya-pada-tubuh.html?m=1. 27 Mei 2018 (11.20)

6) Randukan,p. 2013. Karya tulis ilmiah bahaya merokok. http://pratiwirandukan.blogspot.com/2013 /02/karya-tulis-ilmiah-bahayamerokok.html?m=1. 27 Mei 2018 (15:29)

7) Siyoto, S., \& Sodik, M. A. (2015). Dasar Metodologi Penelitian. Yogyakarta: Literasi Media Publishing

8) Sodik, M. (2015). The "Kimcil" Phenomenon: Sexual Knowledge and Safe Sex Behaviour among Adolescents in Kediri. The 1st Joint International Conference. Retrieved from http://proceeding.tenjic.org/index.php/1JI C/article/view/2

9) Sodik, M. A. (2014). Sikap Pencegahan Aborsi Ditinjau Dari Pengetahuan Tentang Bahaya Dan Resiko Kesehatan. Strada Jurnal Kesehatan http://publikasi. stikesstrada.

ac. i d/wpcontent/uploads/2015/02/9-SIKAPSIKAPPENCEGAHAN-ABORSI. pdf.

10) Sodik, M. A., \& Azwar, S. (2012). ANALISIS KARAKTERISTIK AITEM TES UJIAN SEKOLAH/MADRASAH DENGAN TEORI TES KLASIK DAN TEORI RESPON AITEM (Doctoral dissertation, Universitas Gadjah Mada).

11) Sodik, M. A., \& Nzilibili, S. M. M. (2017). The Role Of Health Promotion And Family Support With Attitude Of Couples Childbearing Age In Following Family Planning Program In Health. Journal of Global Research in Public Health, 2(2), 82-89. https://ojs.stikesstrada.ac.id/index.php/JG RPH/article/view/7

12) Sodik, M. A., Suprapto, S. I., \& Pangesti, D. (2013). Faktor-Faktor Yang Berhubungan Dengan Pelaksanaan Pelayanan Prima Pegawai Di RSUI Orpeha Tulungagung. STRADA. Jurnal Ilmiah Kesehatan, 2(1).

13) Sodik, M. A.,(2016). Leprosy Patients in public perception: A qualitative study of patient confidence (dis) in the Community. Journal of Global Research in Public Health, 2(1), 82-89. https://ojs.stikesstrada.ac.id/index.php/JG RPH/article/view/1 
14) Sodik, M. A.,(2018). Merokok \& Bahayanya. Tegal: PT. Nasya Expanding Management

15) sodik, m., \& Histama, B. (2018). Compliance With The Use Of Protective Equipment And Application Of Standard Operating Procedure On The Occurrence
Of Accidents At Work Employees Part Production In PT. PAMA Persada Nusantara. Indonesian Journal Of Occupational And Environmental Health, 1(1). Retrieved from https://ojs.stikesstrada.ac.id/index.php/IJO EH/article/view/24 